\title{
プローブを用いて地下埋設管の陰極防食レベルを評価する方法
}

\author{
笠 原 晃 明*
}

*東京ガス株式会社技術研究所

\section{A Method for Evaluating the Performance of Cathodic Protection by Means of Analog Probes}

\author{
Komei Kasahara* \\ *Tokyo Gas Company, Ltd., Research \& Development Institute
}

\begin{abstract}
A technique is described for measuring the true pipe-to-soil potential of buried pipelines by means of an analog probe simulating a holiday in a coating on steel. Examples are given comparing data obtained from traditional measurements and the alternate. Results are also described of the practical applications to the field pipe-to-soil potential survey as well as corrosion rate survey.
\end{abstract}

\section{1.はじめに}

1928 年, R. J. Kuhn が初めて地下埋設パイプライ ンに陰極防食を適用して以来既に半世紀有余が過ぎた昨 今，㓌極防食は，埋設管を土壤腐食から守る普遍的な技 術として世界中に定着して拉り，中には米国のように， プラスチック防食塗覆装を施した埋設管に対しては, ご く限られた例外的ケースを除いて陰極防食を適用するこ とを義務ら゙けている国もある。これは，埋設管の場合に は，防食塗覆装といらどちらかといえば passive な防食 法に加えて，陰極防食のような active な防食法を併用 することが，比較的簡便な割には腐食漏沂防止に極めて 有効で, 総合的にみても経済的であることが長年の実績 によって裏付けられているからにほかならない。しか し，このように一見摇るぎない技術であるかのように映 る陰極防食も, 実はいろいろな問題をかかえている。そ の一つが本稿のテーマである防食レベルの評価法に関す るものである。これも元はと言兄ば, 陰極防食が経験的 要素で固められた技術であって，ほとんど理論的背景を 持って扣らず，経験的に導かれたいくつかの指標に適合 するように設計・維持管理されつつも成果だけは上げて 来た婎いがあるが故のるのである。

そもそも陰極防食を施すからには，それが予期した通 り十分に機能しているか否かを評価しようとするのは当 然のことで, そのためには, 評価のクライテリオンが定

* 厂105 東京都港区芝浦 1-16-25 (1-16-25 Shibaura, Minato-ku, Tokyo, 105 Japan)
まっていて，それに要する測定技術も確立されているこ とが前提であることは言を待たない。1 1824 年に，Sir Humphry Davy が，犠牲陽極による陰極防食を発明し た当時は，対象物がボイラーとか船体のようなものであ ったため，目視で確認すれば良く，その時のクライテリ オンは，「腐食の形跡が認められないこと」で十分であ った。しかし，地下埋設管の場合にはそういら訳にもい かないので，地表面から測定出来る何物かによって判定 することが要求されるところとなり，管対地電位のよう な電位による方法，埋設管に流出入する電流を指標とす る方法等が考光出され，1933 年には早くも Kuhn によ って $-0.85 \mathrm{~V}$ vs. $\mathrm{Cu}-\mathrm{CuSO}_{4}$ (以下，本稿では電位はす ベて飽和硫酸銅電極基準で表示する) といらクライテリ オンが提唱されるに至ったのである。その後もいろいろ なクライテリオンが提案され，今ではその数は十指に達 するが(表 1 参照)，そのほとんどは経験的に導かれたも

表 1 陰極防食クライテリオンのいろいろ

1. 防食電流通電時の管対地電位が $-0.85 \mathrm{~V}$

2. 防食電流通電時の電位シフトが $-0.3 \mathrm{~V}$

3. $-0.1 \mathrm{~V}$ の陰分極

4. $E \sim \log i$ 曲線の Tafel 部分の開始点よりも卑

5. 構造物に防食電流が流入していること

6 . 防食電流遮断時の電位が $-0.85 \mathrm{~V}$

7. 電流密度 $10 \mathrm{~mA} / \mathrm{m}^{2}$

8. 目視で腐食が認められないこと

9. テストクーポンで腐食が認められないこと

10. 漏洩がないこと 
のでその根拠が明らかでなく，誰が何時頃言い出したも のかさ定かでないものが多い。

その中で, 測定・評洒法が単純なために最も一般的に 用いられて和り, 若干の理論づけも行われているのが $-0.85 \mathrm{~V}$ クライテリオンで, 対象物がこの電位よりる卑 になるように維持すれば防食が達成されるとするるので ある。ところが，この值は通常，パイプ直上の地表面に 設置された飽和硫酸銅照合電極を用いて求められるすの であるため, 防食電流が土壤あるいは防食塗覆装を横切 って管表面へと到達するのに伴って生ずる，いわゆる $I R$ 降下分の誤差が上乗せされて抒り, 時にこの誤差分 の寄与が著しく大きくて真の值が遮蔽されてしまうこと すらある。-0.85V がその值かどうかの議論は別とし て，腐食反応を完全に抑止するために必要な限界分極電 位が存在することはどうやら間違いなさそうなので，上 述のような $I R$ 成分を含んだ管対地電位を目安にして陰 極防食システムを働かせるさとは，一種の盲運転ともい えるわけで，これは，昨今のように，操業圧力の高圧化 に伴って腐食が許容されなくなって来つつある情勢下に あっては, 由々しい問題であるといわざるを得ない。 さらに最近になって, 応力腐食割れ, 水素応力割れ (hydrogen-stress cracking) あるいは塗覆装の陰極剝離 (cathodic disbonding) といらような単なる腐食とは異 なった形態のパイプラインの損傷の存在が明らかにさ れ，これらがいずれも分極電位と深いかかわりを有して いるため，その防止のためには分極電位 (IR 成分を含ま ないといら意味で真の管対地電位といらょうな呼び方を されることもある）を把握した上でしかるべき措置を講 ずることが不可欠であることが明らかになって来たこと もあって，分極電位を測定する手法，すなわち，IR 成 分を除去しつつ管対地電位を測定する手法の開発が急が れるところとなった。そこで如何にして IR 成分を取除 くかといらことになるが，原理的に最も単純に考㝋る と，照合電極を限りなく対象物の表面に近付けることが 出来れば除去は可能である。しかし地下埋設管ではこれ は一般にむずかしく，特に塗覆装パイプラインの場合に は, 塗覆装の欠䧩 (以下ホリデイ) の位置を探知して, な扮かつ塗覆装の厚さの影響も乗りこえて照合電極を管 表面まで近付けないと分極電位が得られないといらこと になると，これは事実上不可能であるから，これに代わ る手法が必要である。これまでに考兄出された $I R$ 成分 の消去法としては次のようなものがある。

（1）陰極防食の電源を遮断すると，IR 成分は瞬時の うちに消滅するが，管表面の分極電位は，ややしば らく元のレベルに留まっていることを利用する方法 (instant-off potential technique)
（2）複数の陰極防食電源を有するシステムの場合，こ れらを順次遮断して $I=0$ の状態へ外插する方法 (stepwise-current-reduction technique) ${ }^{2)}$

（3）裸埋設管の時, 管-照合電極の水平距離 $r$ を変化 させて，r=0 すなわち $R=0$ の状態へ外挿する方 法 (side-drain technique) ${ }^{2)}$

（4）非平滑化半波整流を陰極防食電源として用い, $I=0$ の瞬間の電位をオシロスコープで読取る方法 (5) 防食電流を規則的に摇動させた時の電位の応答か ら $I R=0$ の状態を推定する方法

これらの方法は，いずれる $I R$ 成分のうち $I$ 㕛は $R$ のいずれかをゼロにするか, あるいは外挿によってゼ口 の状態を推定するという考方方に基づいて打り，いずれ も一応の成果を上げている。しかしこれらの手法に共通 している問題点は, 多数の陰極防食電源を同時に遮断す ることが技術的にむづかしく，さらに，軌道からの迷走 電流や地電流といった，源で遮断出来ない，乙かも非定 常な干渉電流が存在している時, あるいは, 犠牲陽極方 式の陰極防食のように電流を遮断しにくい場合には, そ の寄与を排除することが事実上不可能であるため, 分極 電位が求まらないことである。

そこで考え出されたのが，塗覆装の欠陥，いわゆるホ リデイをシミュレートしたプローブ (measuring probe) をパイプラインに取付け，これをパイプラインから切放 したり再び接続したりすることによって $I=0$ の状態を シミュレートしようとする方法である。この方法は，著 者ら゙)をはじめ, 西独の Baeckmann ${ }^{4)}$ ，チェコスロバキ アの Polak ${ }^{5)}$ 等によってほぼ時を同じくして開発され， 最近ではオーストラリアやオランダでも同じような試み が始められている。本稿では, 著者らが開発した手法の 原理と応用例について紹介することにする。

\section{2. 測定法の原理}

前述のように，地下埋設管では，照合電極を管表面に 無限に近付けることによってRをゼロにし，それによっ て IR 成分を除去するということは不可能であるから， $I$ をゼロとする以外飞方法はない。では，迷走電流の ようにその源で遮断出来ない干渉電流が存在する時でも Iを事実上ゼロとする方法はないであろらかと考觉たの が，プローブを用いる方法を開発したきっかけである。

今, 埋設管のホリデイに，防食電流だけでなく迷走電 流等の干渉電流も流入している状況を想定すると, そも そもこの管がこのような電流の影響を受けるのは，当然 のことながら，埋設管が，電流の流出部も含めて畄路を。 提供しているからにほかならない。従ってこれを排除な いしは遮断出来れば $I R$ 成分を除去出来ることになる。 


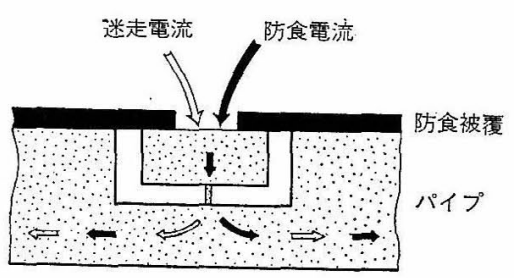

図 1 プローブの原理図

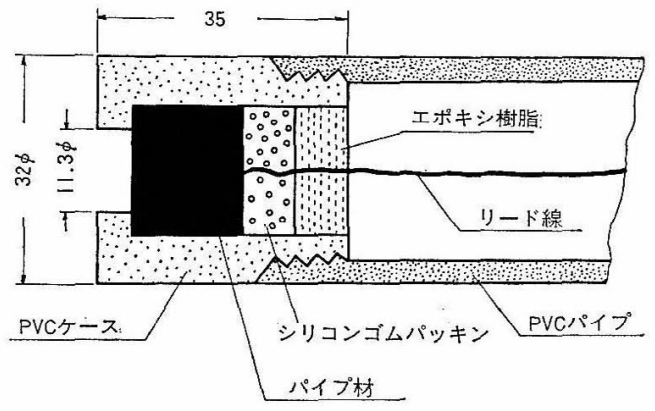

図 2 プローブの構造

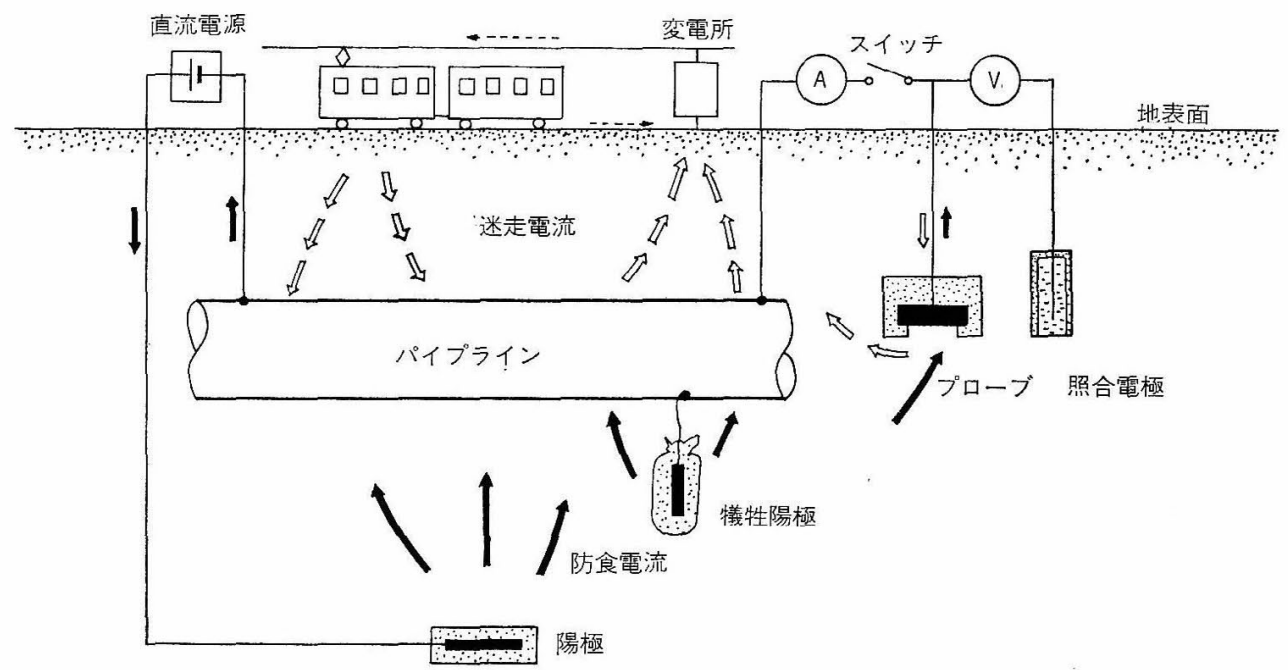

図 3 プローブを用いる管対地電位測定の原理図

そこで図 1 のよらに，ホリデイ值下のパイプ・マトリッ クスの一部が浮島として存在している状況を想定する。 るしこの浮島がマトリックスと電気的につながっていれ 代，浮島上のホリデイは，電気化学的意味でパイプの他 のホリデイと等洒である。ここで浮島をパイプ・マトリ ックスから切放すと，その瞬間にホリデイを経てパイプ マトリックスへと流入していた電流も止まることになる ので, $I=0$ の状態が現出するはずで㐫る。従って，この 浮島をパイプ系から取出した形のbのを用い机ば分極䉓 位が測定出来るはずである。こうして考光出されたるの がプローブで，その構造は図2 に示す通りである。プロ ーブの先端には，塗覆装のホリデイ部を想定した深さと 面積とを有する空が設けられており，その底にパイプと 同一材筫の金属板が埋め込亲れている。

図 3 は，プローブを用いる管詨地電位測定法の原理を 示す図である。基本的には，上述のプローブのほかに， 照合電極，電位差計，スイッチの三つがあれば測定には 十分で，これらな図のように接続して，プローブとパイ プとをつないでいる回路を遮断すれば，その瞬間に分極

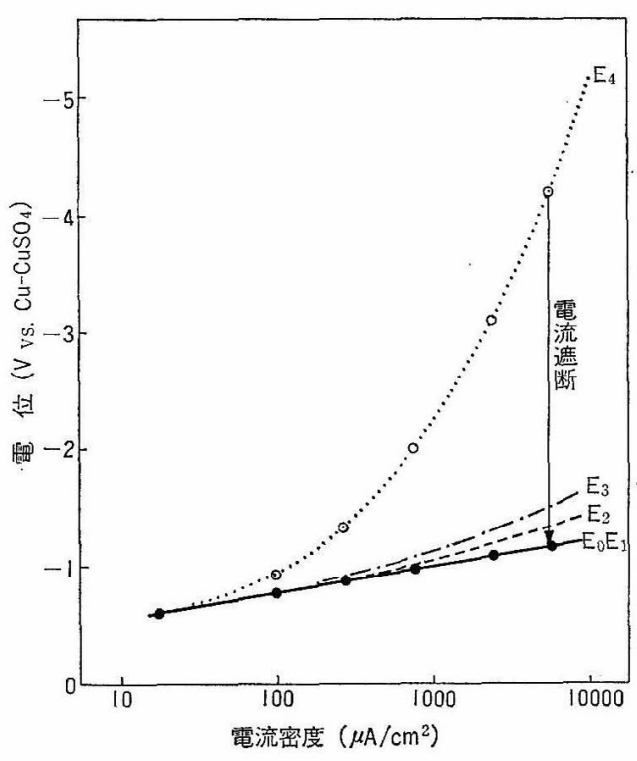

図 4 種々の管対地電位測定法で求めた分極曲線 
電位が得られることになる。なおこの際,プローブとパ イプとを結ぶ回路に電流計を㨂入して打けば，プローブ に出入りする電流の密度も同時に知ることが出来る。こ の，電流の向きと大きさがわかるということは，陰極防 食システムの維持管理にとって大变好都合である。

図4は，このような方法で本当に分極電位が測定され ているか否かを確かめる目的で行った試験の結果であ る。ここで， $\mathrm{E}_{4}$ は照合電極を地表面に設置する従来か らの方法によるもの， $\mathrm{E}_{3}, \mathrm{E}_{2}$ は, 照合電極をホリデイの 至近距離に設置した時のもの， $\mathrm{E}_{1}$ はプローブによるも の， $\mathrm{E}_{0}$ は防食電流をその源で㵂断した時のものである。 $\mathrm{E}_{4}, \mathrm{E}_{3}, \mathrm{E}_{2}, \mathrm{E}_{0}$ の比較から, 通常の管対地電位测定法であ る照合電極を地表面に設置する方法では $I R$ 成分が顕著 であるが，照合電極を金属表面に近付けるに従って，防 食電流遮断㨁後に得られる分極電位 $\mathrm{E}_{0}$ に近付くものの, 照合電極とホリデイの底の金属表面との間の微小な間吵 で生ずるIR 降下は物理的に不可避で, 特に電流密度の 大きい領域では無視しがたいことがわかる。これに対し てプローブとパイプとを結ぶ回路を開にした時得られ る電位 $\mathrm{E}_{1}$ は，分極電位 $\mathrm{E}_{0}$ と完全に一致している。す なわち，プローブを使用すれば，防食電流あるいは他の 電流が流れているいないにかかわらず分極電位を求める ことが出来る。

\section{3. 測定法の実際}

実際の測定では, 図 3 の測定原理図の電位差計として 入カインピーダンス $1 \times 10^{5} \mathrm{M} \Omega$, 入出力電生比 $1: 1$ の 市販のエレクトロメーター, 電流計として零抵抗電流 計，スイッチとしては, 開時間 0.6 1.0 秒, 閉時間 10〜 20 秒の笪囲で可变の 自動反復開閉器 (current interrupter）を用いることとし，これらすべてを組込んだ測 定器 (Pipeline Corrosion Protectometer, 写真 1 参照) を製作してこれと2現象記録計とを組合わせ使用乙 た。測定手順としては，まず，プローブと照合電極とを 埋設管の近傍に設置する。その位置は, 対象とする埋設 管の電気化学的環境条件 (主として土壌環境) を正確沉 シミュレートするため出来るだけ埋設管に近い万が良 くまた，プローブと照合電極との間隔もあまり離さな い方が良い。次にリード線を用いてプローブを埋設管に つなぎ込み，プローブ先端の金属/土壌界面が十分分極 されるまで放置する。これには少なくとも一週間程度は かかるが，これを行うことによってプローブは，電気化 学的意味において埋設管と等価になる。次に写真 1 の測 定器を插入して，10 20 秒ごとに 0.6 1.0 秒間プロー ブと埋設管との間に流れる電流を遮断し，その時の電 位，電流の経時変化をレコーダーに記録すれば，通常の 测定法によるIR 降下分が上乗せになっている管対地電



写真 1 プローブを用いる管対地電位，電流密度測 定のための測定器

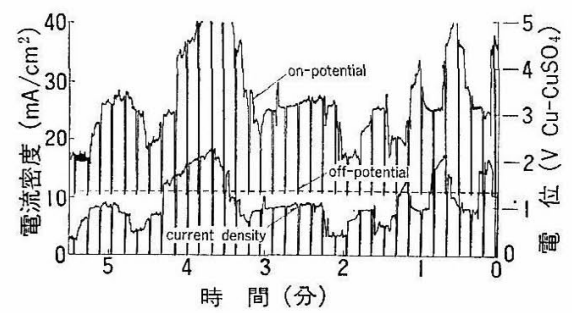

(a) 日中電車運行時

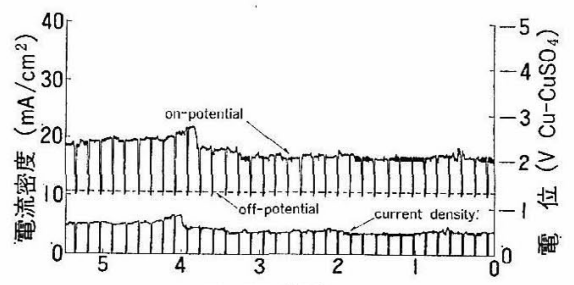

時 間(分)

(b) 夜間運転終了後

図 5 プローブによる管対地電位, 電流密度測定例 ${ }^{33}$

位 (以下 on-potential), 分極電位 (以下 off-potential), 電流密度の三つが同時に求方ことになる。

図 5 は，電車軌道からの迷走電流が犠牲陽極力式の陰 極防食システムを干渉している地点に和ける実測例で，

（a）は日中の電車運転時，(b) は夜閒の運転休止時のデ 一タである。前者では，迷走電流を主成分とするホリ デイ流入電流の激しい変化に完全に同期する形で onpotential が変動しており，その幅は， $-2 \mathrm{~V} \sim-6 \mathrm{~V}$ に

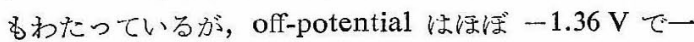
定である。一方，後者では迷走電流による干淑が流とん ぞなくなり，ほぼ防食電流だけが流入している状態であ るが, on-potential への $I R$ 降下分の寄与は依然として 残っており, off-potential $-1.32 \mathrm{~V}$ に対して IR 降下 は $0.7 \mathrm{~V}$ もあるすなわち，従来の照合電極を地表面に 設置して行ら管対地電位測定では，IR 降下の奇与が無 視出来ず，特に，迷走電流が陰極防食システムを干渉し ている場合には著しい誤差をむたらすことが明らかであ る。これに対して，プローブを用いる測定では，防食電 流，迷走電流が流れているままでも，その影響を受ける 


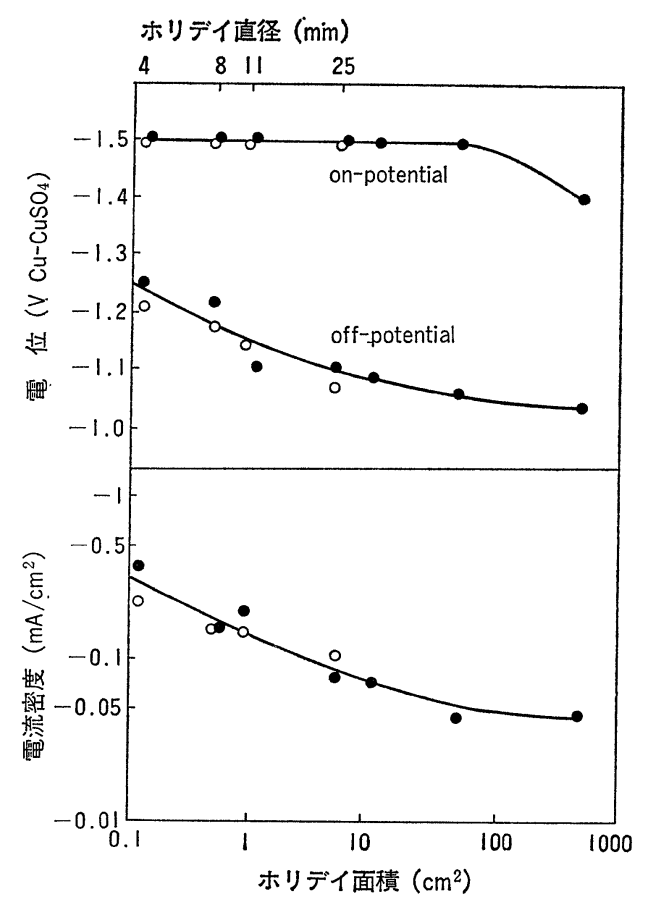

図 6 ホリデイ面積が管対地電位, 電流密度に及ぼ す影響10)

ことなく分極電位が得られている。

さて，前述のように，プローブは埋設管のホリデイを シミュレートしたものであるが，実際のパイプラインで はさまざまな形状, 次元のホリデイが混在しているはず である。ホリデイの大きさが変わると，そこに流出入す る電流の密度も変わるために, 電気化学的状態にも変化 が現われて来ることは想像に難くない。従って,プローブ のホリデイの大きさとしてどのようなるのを用いるべき かが問題になる。図 6 は, ホリデイの面積を $3 \mathrm{~mm}^{2} \sim$ $500 \mathrm{~cm}^{2}$ の範囲で変えて, 電位和よび電流密度に及ぼす 影響を見た結果である。当然のことながら, ホリデイ面 積が増すにつれて流入電流密度は減少する傾向にあり， 電流密度に依存している分極電位，すなわち off-potential b同じような挙動を示しているが, $10 \mathrm{~cm}^{2}$ 以上 ではほぼ一定の值をとっている。従って, $10 \mathrm{~cm}^{2}$ 以上 のホリデイを有するプローブを用いて off-potential が あるクライテリオンを満足するように維持すれば，他の いかなる次元のホリデイに抢ける分極電位もそれよりる 貴になることはあり得ないから安全側の評価が出来る わけで, Ruhrgas 社 (西独) では $30 \mathrm{~cm}^{2}$, The Australian Gas Light 社（オーストラリア）では $40 \mathrm{~cm}^{2}$, Gasunie 社 (オランダ) では $20 \mathrm{~cm}^{2}$ のプローブが使用 されている。このように, 予想し得る最大級の大きさの ホリデイを有するプローブで防食状況を評価する方法 は, 従来の陰極防食電流をその源で遮断して得られる off-potential を用いて評価する方法よりも安全側の指標 を与える。それは，防食電流をその源で遮断した時に現 われる off-potential は, いま存在している各ホリデイ における分極電位の総平均であるから，図6でわかるよ らに，例えば $1 \mathrm{~cm}^{2}$ のホリデイを基準にとれば，電位で は, $\pm 100 \mathrm{mV}$, 電流密度では $\times 2 \sim \times 1 / 4$ の幅のあいま いさを伴っているわけでこの平均分極電位がちょうど防 食のクライテリオンを満足しているケースでは, 平均よ りも大きいホリデイ部が適正防食レベルを割ることにな るからである。

以上は，埋設管およびプローブが，腐食電位に対して カソード側に分極されている場合の話であるが，マクロ セル腐食や，迷走電流の流出による腐食のような active な腐食が起こるような状況下では，埋設管执よびプロー ブは，腐食電位に対してアノード側に分極されるため， 各電位の関係は，(カソード側）腐食電位@off-potential (大口径のプローブ，ホリデイ部) ミoff-potential (小ロ 径のプローブ，ホリデイ) ミon-potential (アノード側) といらょうに, 電流が流入している時とちょうど反対に なる。電流が流出する状況下で早く腐食されるのは小さ いホリデイの部分であるから，大口径プローブによる off-potential 又は電流密度を用いると, 不安全側の判定 をする危険性が出て来る。従って, むやみに大きい口径 のプローブを用いることは好ましくないといえる。

\section{4. プローブによる陰極防食レベルの評価例}

\section{1 地下埋設管における管対地電位と電流密度}

まず初めに, on-potential と off-potential ならびに 電流密度が実際の埋設管でどのような関係になっている かを, 約 100 地点にのぼる現場測定を通じて調べた結果 を紹介する。測定の対象とした埋設管は，ポリェチレ ン, ニールタールエナメル, アスファルトジュート, PVC テープのいずれかを防食塗覆装とする鋼管ライン で, 防食の状況は, 外部電源あるいは犠牲陽極による陰 極防食が施されている埋設管, 陰極防食されていない埋 設管，マクロセル腐食が進行中の埋設管といらように多 岐にわたっている。又，测定点は，出来るだけ広い範囲 にわたって傾向をつかむという意味で，パイプライン事 業法で義務つけられている定期的な管対地電位測定にお いて，その維持管理基準と定められている $-0.85 \mathrm{~V}$ か らの偏倚が大きく出た地点を意識的に拾い出したもの で，各地点に持ける土壤比抵抗す $1000 \sim 25000 \Omega \cdot \mathrm{cm}$ と いらように広範囲にわたっている。現場測定データは, 図 5 の例のように時間とともにかなり変動するため, そ の平均值を以って整理したが，その結果, on-potential が $-9.05 \sim-0.24 \mathrm{~V}$, 電流密度は $-12.1 \sim+0.24 \mathrm{~V}$ と 変動している時, off-potential は $-1.50 \sim-0.55 \mathrm{~V}$ と 


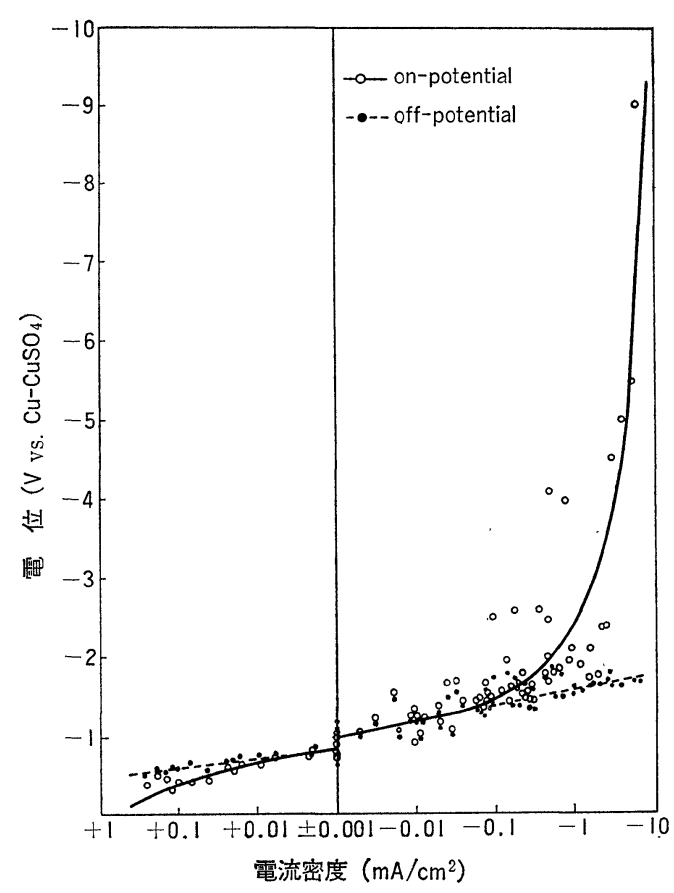

図 7 埋設管に括ける on-potential, off-potintial, 電流密度の関係

いうように比較的狭い領域に分布していた。なお，ここ で正の電流密度は埋設管から電流が流出していること, すなわち腐食が進行していることを示している。電流密 度から明らかなように，測定データはカソード，アノー ド両域にまたがっているので, 便宜上, $-0.001 \mathrm{~mA} / \mathrm{cm}^{2}$ より負な電流密度のデータをカソード領域, $+0.001 \mathrm{~mA}$ $/ \mathrm{cm}^{2}$ よりる正のデータをアノード領域とした。又，こ の中間の $+0.001 \sim-0.001 \mathrm{~mA} / \mathrm{cm}^{2}$ の領域では, 不安 定な微小電流が小刻みに流入流出をくりか兄して招り， 金属表面に多数の局部電池が形成されてゆっくりと腐食 が進行している状態と考えられるため，自然腐食領域と して分類した。四7は，測定データをこのような電流密 度の区分に従って，電流密度と電位との関係でプロット したものである。眓中の各最適曲線は最小自乗法で求め たものであるが，数式で表わすと次のようになる。

$$
\begin{array}{ll}
\text { カソード領域 } & E_{\text {off }}=-0.151 \log |i|-1.35 \\
& E_{\text {on }}=-0.195 \log |i|+0.92 i-1.57 \\
\text { アノード領域 } & E_{\text {off }}=+0.107 \log i-0.49 \\
& E_{\text {on }}=+0.204 \log i+0.34 i-0.22
\end{array}
$$

自然腐食領域 $E_{\text {off }}=E_{\text {on }}=-0.84$

ここで $E_{\text {on }}$ は on-potential (V), $E_{\text {off }}$ は off-potential (V), $i$ は電流密度 $\left(\mathrm{mA} / \mathrm{cm}^{2}\right)$ である。off-potential の 式を見ると，カソード，アノード領域共に，

$$
E_{\text {off }}=a \log |i|+c
$$

の形で表わされているが，この形は Tafel の式にほかな
らない。従って, off-potential は, 埋設管のホリデイに 流出入する電流による分極電位を示していると結論する ことが出来る。off-potential に対する電流密度の影響は このように対数できいて来るので, $100 \mathrm{~mA} / \mathrm{cm}^{2}$ という ような大電流が流れ込む状態でも， off-potential はたか だか $-1.65 \mathrm{~V}$ どまりである。英国規格 BS CP 1021 で は， $-2 \mathrm{~V}$ 以上を過防食と定義しているが，真の管対地 電位でいらとこのような電位は実用上あり得ないことに なる。一方, on-potential は,

$$
E_{\mathrm{on}}=a^{\prime} \log i+c^{\prime}+b^{\prime} i
$$

の形で表わされているが，この中の係数 $a^{\prime}, c^{\prime}$ を $E_{\text {off }}$ の式の係数と比較すると, カソード，アノード領域いず れにおいてもほぼ同じ值を示している。すなわち， $E_{\text {on }}$ と $E_{\text {off }}$ とは, $E_{\text {on }}=E_{\text {off }}+b^{\prime} i$ の関係にあり, $b^{\prime} i$ がい わゆる $I R$ 降下分に相当していることになる。上式の中 の $a, a^{\prime}, b^{\prime}$ 等の係数は, 土㙞の特性值や, 被覆欠陥の大 きさ等に依存して変化するので, 回帰式乞のものにはあ まり意味はないが，多くの測定データの平均的傾向を最 小自乗法による回帰でとらえた時に，on-potential が， 流出入電流による分極電位と $I R$ 降下分の和となって現 われて来た点が興味深いといえよう。四から明らかなよ 亏に, $|i|>0.1 \mathrm{~mA} / \mathrm{cm}^{2}$ の領域では $I R$ 降下の寄与が無 視出来ず，特に $1 \mathrm{~mA} / \mathrm{cm}^{2}$ 以上のいわゆる過防食領域 では, on-potential の大部分は $I R$ 降下で占められてい る。これに対して $|i|<0.1 \mathrm{~mA} / \mathrm{cm}^{2}$ の領域では, IR 降 下の寄与が比較的小さいため, 従来の方法による onpotential でも泳济分極電位に近いものが測定されてい たことになる。このように多くのデータの平均で見る と, $E_{\mathrm{on}}, E_{\mathrm{off}}, i$ の間にはかなり良い相関があり, 例光ば on-potential が $-1.2 \mathrm{~V}$ よりも卑であれば off-potential も $-1.0 \mathrm{~V}$ よりる卑になるから，わざわざ offpotential を知る必要はないかのように映る。しかし， on-potential は, 土壤環境, 被覆抵抗等に左右されて ラッキが大きいため，これだけで防食状沉を絶対評価す ること，すなわち，分極電位や電流の極性と大ささを推 定することは危険であり, やはり分極電位と電流密度を 抑えることが必要である。

な扮，自然腐食領域の電位の平均值が $-0.84 \mathrm{~V}$ と いらことは，従来の陰極防食のクラリテリオンである $-0.85 \mathrm{~V}$ が必ずしも適切でないことを示唆していると考 えられる。この点については次節で詳しく触れる。

上述の上うに，実際の埋設管に淤ける電位，電流密度 は非常に幅広い分布を見せているが，測定データを電流 の極性と大きさ，電位のレベル，それらの経時変化の仕 方の点から見ると, 図 8 のような四つの典型的なパター ンに分類することが出来る。(a) では，迷走電流の影響 る小さく,そのため電流密度, 電位共にあまり変動して 


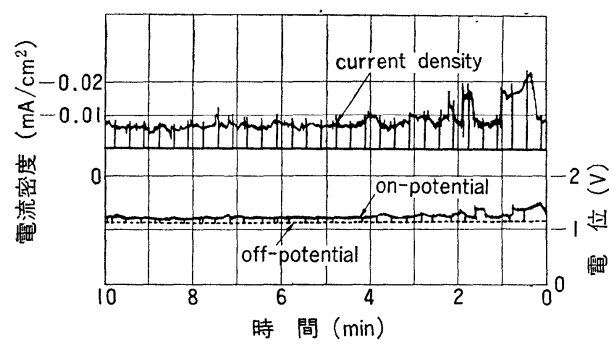

(a) 適正防食

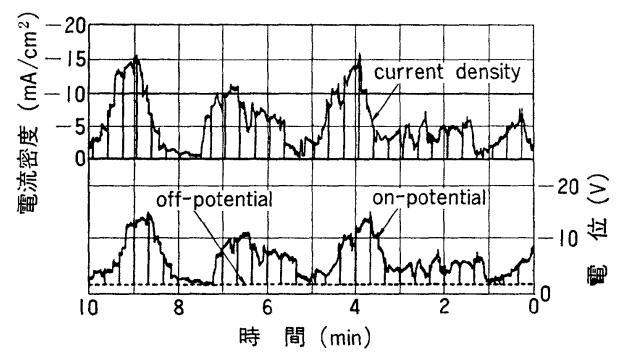

(b) 過防食

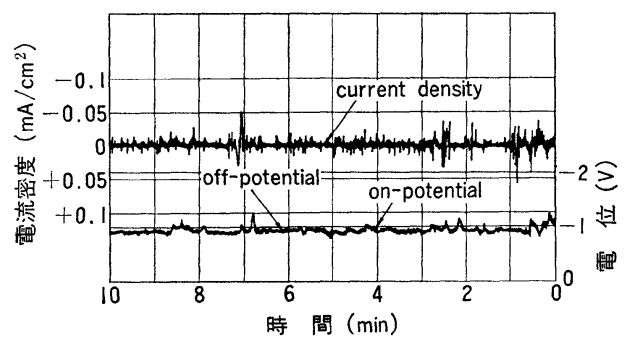

(c) 自然腐食

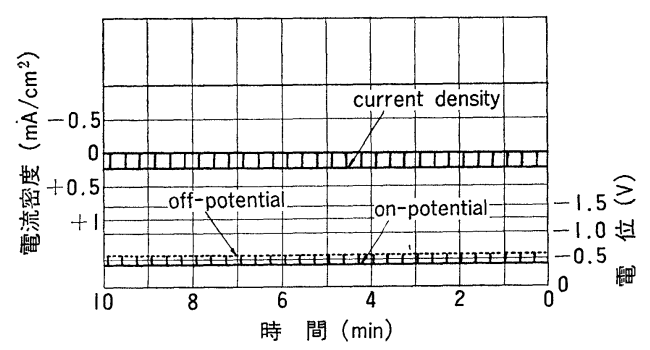

(d) マクロセル腐食

図 8 埋設管の防食状況による測定データのパター ンの変化 ${ }^{10}$

いない。ホリデイには, 常時 $0.1 \mathrm{~mA} / \mathrm{cm}^{2}$ 程度の防食電 流が流入して, $-1.1 \mathrm{~V}$ と適正なレベルの分極電位が達 成されている。(b)は, 図 5 (a) と同じく, 迷走電流が埋 設管に干渉している状態で, もし防食塗覆装に欠宿があ れば，そこから大きな迷走電流が流入し，ホリデイ内を 強アルカリ環境にするため, 防食塗覆装の剥離一cathodic disbonding一を起こしかねない状況にある。防食 塗覆装に悪影響を及ぼしかねない程の大電流が流入して
いるともかかわらず, off-potential は $-1.45 \mathrm{~V}$ と, (a) よりも $0.35 \mathrm{~V}$ 卑寄りになっているに過ぎない。こ のことは, プローブを用いることによって初めて明らか になる電流密度が，陰極防食システムの維持管理の重要 な指標になることを意味している。次に (c) は，微弱な 電流が $-0.01 \sim+0.01 \mathrm{~mA} / \mathrm{cm}^{2}$ の間を変動しており, そのアノード成分によりわずかながら腐食が進行中であ ると推定される。電流が微弱で $I R$ 成分が無視出来るた め, on-potential と off-potential は同レベルにある。 他の三つのケースでは off-potential はほぼ一定であっ たが, この場合には, 電流の極性の反転, 増減に対応し て $-0.85 \sim-1.20 \mathrm{~V}$ の間で変動しているのが特徵であ る。最後の (d) では, もし防食塗覆装に欠陥があれば, そこから常時 $0.24 \mathrm{~mA} / \mathrm{cm}^{2}$ の電流が流出し, 理論計算 上は $2.9 \mathrm{~mm} / \mathrm{y}$ の速度で腐食が進行する状沉にある。著 者らは，以上の四つのケースをそれぞれ，適正防食，過 防食, 自然腐食, マクロセル腐食と呼んでいるが，この 区分けは，プローブを用いた測定チャートを一見するだ けで可能である。

\section{2 陰極防食のクライテリオン}

本稿の冒頭でも述べたように，陰極防食のクライテリ オンはいまだ確立されて抢らず，最も準拠することの多 い一 $-0.85 \mathrm{~V}$ クライテリオンでさえ, 完全防食達成電位 ではないのではないかという疑問をはさむ向きが少なく ない1)。前節で紹介した現場測定の結果でも，自然腐食 領域に打ける平均分極電位は $-0.84 \mathrm{~V}$ となって打り, $-0.85 \mathrm{~V}$ クライテリオンが必ずしも適当でないことが示 唆されている。このようにクライテリオンが未確立なの は, 英国規格 BS CP 1021-1973 の規定にもあるように, 土壤の嫌気性の寄与により限界電位が変わって来るため 一概に決められないためもあるが，地下埋設管の分極電 位を測定する手法が確立されていなかったために，分極 電位を制御ないしは監視した試験を行らことが出来なか ったことに最大の原因がある。そこで著者らは，プロー ブを用いて分極電位を抑えつつ実験室ならびに現場で土 猿埋設試験を行い, 腐食速度と分極電位, 電流密度との 関係を調べた。実験室試験では, $1 \mathrm{~cm}^{2}$ のホリデイを有 するプローブ 3 個を 1 組にして土壤に埋設し，定電流制 御で 6 ケ月間放置後重量変化を測定し，腐食速度に換算 した。試験に供した土壤は, 比抵抗 $12000 \Omega \cdot \mathrm{cm}$ の砂 質土, $7800 \Omega \cdot \mathrm{cm}$ の関東ローム, 関東ロームに $1 \%$ の $\mathrm{NaCl}$ 又は $\mathrm{CaSO}_{4}$ を添加することにより，それぞれ 110 $\Omega \cdot \mathrm{cm}, 1100 \Omega \cdot \mathrm{cm}$ に調整したものの 4 種である。一方 現場試験では, 同じ次元のプローブを埋設管の直上 0.3 $\sim 0.5 \mathrm{~m}$ の土壌中に設置し, 埋設管につなぎ込んで 6 ケ 月放置した後，重量変化を測定した。

因 9 は, 試験結果を, 電流密度〜腐食速度の関係で整 


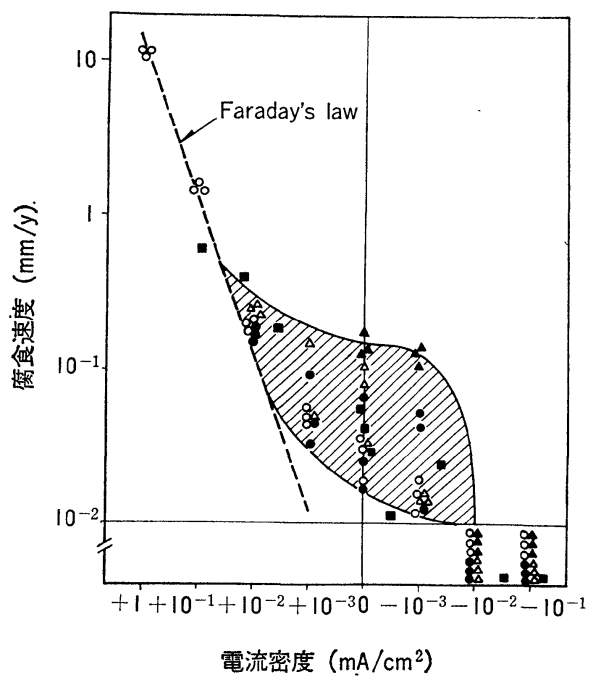

- 現場試験データ

$\triangle$ 砂 質 土 $12000 \Omega \mathrm{cm}$

$\bigcirc$ 関東ローム $7800 \Omega \mathrm{cm}$

$\Delta$ 関東ローム $+1 \% \mathrm{CaSO}_{4} \quad 1100 \Omega \mathrm{cm}$

- 関東口-ム $+1 \% \mathrm{NaCl} \quad 110 \Omega \mathrm{cm}$

図 9 土壌腐食速度に及ぼす電流密度の効果 ${ }^{11)}$



図 10 土壤腐食速度と分極電位の関係 ${ }^{11}$

(Symbol は図9にじ)

理したものである。+ $+10^{-2} \mathrm{~mA} / \mathrm{cm}^{2}$ よりも正（アノー ド）側では，腐食速度は Faraday の法則通りの変化を 見せているが， $+10^{-3} \sim-10^{-3}$ の自然腐食領域では，

Faraday の法則からの偏倚が顕著で，かつバラッキも大 きくなっている。これよりもカソード側の $-10^{-2} \mathrm{~mA} /$ $\mathrm{cm}^{2}$ よりも負な領域では, 腐食は完全に抑制されてい る。

因 10 は，試験結果を分極電位〜腐食速度の関係で整
理したものである。な抢ここでは，分極電位として，試 験開始後 6 ケ月目のるのを使用しているが，これは，分 極電位が平衡に到達するのに 1 週間 1 ケ月を要するこ とを考慮したものである。図に見られるように， -0.85 V〜-1.0V の領域では，いまだ無視出来ないオーダー の腐食が認められるが， $-1.0 \mathrm{~V}$ よりも負な領域では， 腐食は完全に抑制されている。

腐食抑制に要する限界電位を実験的に求めようという 試みは，全く無かったわけではなく，今から 30 年以上 前に, Ewing'), Sudrabin ${ }^{7)}$, Schwerdtfeger ${ }^{8)}$ らが，そ れぞれ独自に展開したことがある。その中で，彼らは例 外なく $-0.85 \mathrm{~V}$ よりす卑な領域でわずかながら腐食減 量を認めたにもかかわらず，その原因を，分極が十分に 進んでいなかった期間に鹵してしまい， $-0.85 \mathrm{~V}$ が限界 電位であると結論付けている。しかし，図8(c)の現場に 拈ける実測データが示しているように，分極電位が平均 として, $-0.90 \mathrm{~V}$, 変動幅でいっても $-0.85 \sim-1.20 \mathrm{~V}$ と, 従来の $-0.85 \mathrm{~V}$ クライテリオンでは完全防食に分 類される状態であっても，電流は流入成分でのみ占めら れているわけではなく， $-0.01 \sim+0.01 \mathrm{~mA} / \mathrm{cm}^{2}$ の間で 小刻みに流入・流出を繰返している状態にある。このこ とは，そのアノード成分に上る腐食が無視出来ないこと を意味して抢り，現にこのプローブでは， $0.02 \mathrm{~mm} / \mathrm{y}$ の 速度の腐食が観察されている。すなわち，ホリデイに微 小電流が流出入を繰返している自然腐食領域では，その カソード成分の寄与のために電位はかなり卑側に行く が，アノード成分の寄与による腐食は依然として進行す るというような状況になっている場合があり得るわけ で，定電流制御試験の $-0.85 \sim-1.0 \mathrm{~V}$ 領域で観察され た腐食を，一概に分極が不完全であった時期に対応する あのと決めつけてしまうわけには行かないことを示して いると考兄られる。

さて, 図 9 と図 1.0 から, 分極電位 電流密度の関係 を求めると図 11 のようになる。ここで図中の破線のよ らに，電位を， $-1.0 \mathrm{~V}$, 電流密度を $-0.01 \mathrm{~mA} / \mathrm{cm}^{2}$ で 区切ると，腐食域と防食域がきれいに分離される。すな わち,

(a) 分極電位が $-1.0 . \mathrm{V}$ よりも卑

(b) 防食電流の流入量が $0.01 \mathrm{~mA} / \mathrm{cm}^{2}$ 以上 のいずれか一方が満たされていれば防食が達成されるの でこれが院極防食の新しいクライテリオンとなり得る と考えられる。な和，ここでは，電流密度を $0.01 \mathrm{~mA} /$ $\mathrm{cm}^{2}$ としたが, 図 11 からは, $0.005 \mathrm{~mA} / \mathrm{cm}^{2}$ あれば一 応は十分である。この值は，Uhlig早）゙，通気性の良い 中性土壤中に掠いて鋼を陰極防食するのに必要な電流密 度の下限としている $0.004 \mathrm{~mA} / \mathrm{cm}^{2}$ と奇しくも一致して いる。BS CP 1021 では，硫酸塩還元菌の作用が活発な 


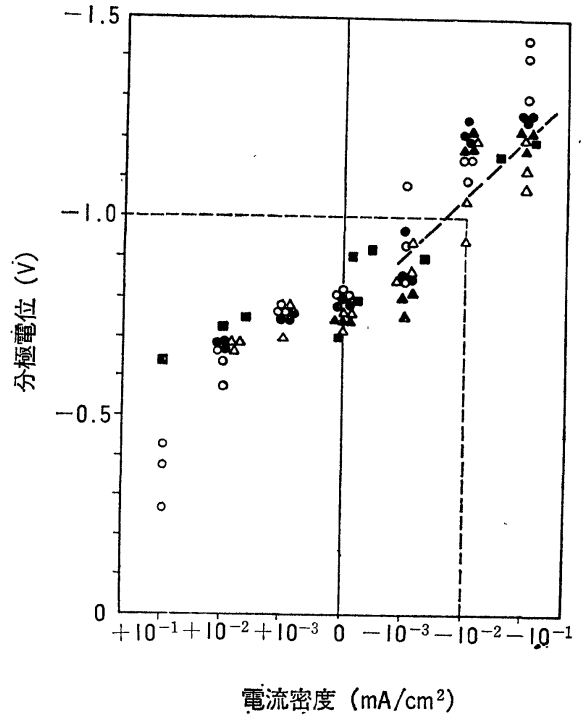

図 11 分極電位と電流密度の関係 ${ }^{11)}$ (Symbol は図9に同じ)

土畩の場合には，中性土壤に対するクライテリオンに $-0.1 \mathrm{~V}$ の上乗せをした $-0.95 \mathrm{~V}$ を用いることを規定 している。著者らが対象としている埋設環境の中には， 嫌気性の環境が少ないため，プローブを用いる手法に よるクライテリオンの見直しはをだ済んでいないが， Uhlig9) がいっている $0.045 \mathrm{~mA} / \mathrm{cm}^{2}$ を信用すれば，そ の時の電位は $-1.15 \mathrm{~V}$ と $0.15 \mathrm{~V}$ 卑寄りの值になる。 以上は腐食/適正防食の境界のクライテリオンに関する ものであるが，適正防食/過防食の境界についてもまだ 定説がない。これも，分極電位，電流密度の観点からの 評価がこれまでにほとんど行われたことが無かったこと に原因がある。過防食によってもたらされる弊害は，防 食塗覆装の剝離と水素応力割れの二つで, いずれも水素 の発生によりもたらされるものであるから，その発生傾 向の電流密度依存性とその影響の仕方が問題になるわけ であるが，同じ量の水素でも，塗覆装，管の材質によっ て影響度が違って来るため，著者らすまだ完全には限界 を把握してないが，一応 $1 \mathrm{~mA} / \mathrm{cm}^{2}$ を許容し得る上限と 考えている。この時の 分極電位は, 先の回帰式から, $-1.35 \mathrm{~V}$ になる。

以上から，著者らが推奖する適正防食レベルは，分極 電位 $-1.0 \sim-1.35 \mathrm{~V}$, 流入電流密度 $0.01 \sim 1.0 \mathrm{~mA} / \mathrm{cm}^{2}$ となる。

\section{3 その他の応用}

例 9 図に示したように，埋設管が腐食電位に対してア ノード側に分極されて，activeな腐食が進行する状況に ある場合には，プローブから流出する電流密度を基に， 腐食速度を推定することが出来る。図 12 は, マクロセ ル腐食が発生した地点で測定された, 流出電流密度と腐

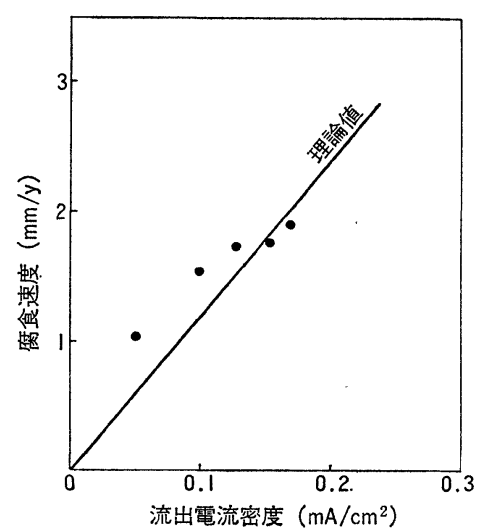

図 12 プローブ流出電流密度と腐食速度の関係 ${ }^{10)}$

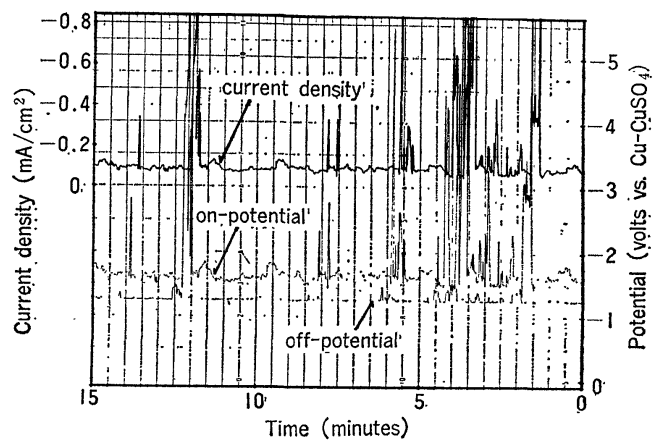

図 13 改良型測定器による電位電流密度の連続記 録例

食速度との関係をプロットしたもので，直線は理論腐食 速度を示している。管の肉厚と，埋設から漏洩に至るま での時間から腐食速度を算出したため，かなりの不確定 要素が含まれているにもかかわらず，比較的良く理論值 と一致している。

最後に多少手前味噌ではあるが，著者らが最近使用し ている測定器を紹介させていただく。当初使用していた 装置は，プローブーパイプ間の回路の開閉に伴う電流， 電位の変化を隈無くレコーダーに描かせるタイプのもの であったため，例えば図 5 のように，データが不連続か つ繁雑で見にくいといら点のほか，レコーダーのペン の応答速度上の制約から, off-period をある程度長くせ ざるを得なかったため, off-potential が不正確になり, しかも不連続測定のために細部がわからないという致命 的な欠陷があった。そこで, on-potential, off-potential を sample and hold 法を用いて分離することで連続記 録を可能にし，off-period を 10〜100 m sec に短縮する ことによって十分な精度が得られるようにし，さらに， 特殊な回路を用いて区間積分することによってノイズを 完全に除去出来るような機能も持たせた装置を製作し た。図 13 は, 電位・電流密度の経時変化が激しい迷走 
電流の強制排流点で， 1 秒ごとに 0.02 秒 の off-period を設けることによって得たデータである。眓 5 と比較し ていただけば改善点は一目瞭然で，以前には捕えられて いなかった off-potential の細かな変化が連続的に捕兄 られている。この装置は, $270 \times 280 \times 120 \mathrm{~mm}$ と非常に コンパクトな割にはいろいろな機能を内蔵しており, AC/DC 共用で内蔵している乾電池でも動かせるため, 管対地電位の現場測定に便利であるばかりか，腐食試験 に打注分極電位測定, 液抵抗測定にも適して括り, 高 感度の零抵抗電流計, 電位差計（入力インピーダンス $10^{10} \mathrm{M} \Omega$ 以上）としても使用出来る。

\section{5. むすび}

プローブを用いると，現に今埋設管に存在しているホ リデイ, あるいは将来もたらされるかるしれないホリデ イに持ける電気化学的様相 (分極電位と電流密度) を正 確に把えることが出来るため, 陰極防食システムの維持 管理には非常に有用で，また，それを埋設管に接続した ままにして执いても何ら悪影響を及ぼす心配が無いた め, 既に built-in で使用している所もあり，今後ますま
す広く使用されるようになるものと考穴られる。

(1981 年 6 月 30 日受理)

\section{文献}

1) A. C. Toncre: "6th European Congress on the Metallic Corrosion", p. 365, BHRA (1977).

2) AGA Pipeline Research Committee: "1979 Pipeline Research Summary”, p. 41, AGA (1979).

3) K. Kasahara, T. Sato and H. Adachi: Mater. Perform., 18, No. 3, p. 21 (1979).

4) W. von Baeckmann, N. Schmitz-Pranghe and W. Schwenk: "Proceedings of the 2nd International Conference on the Internal and External Protection of Pipes", p. J1-1, BHRA (1978).

5) J. Polak: ibid., p. J2-19 (1978).

6) S. P. Ewing: Corrosion, 7, p. 410 (1951).

7) L. P. Sudrabin: ibid, 7, p. 417 (1951).

8) W. J. Schwerdtfeger: ibid., 7, p. 418 (1951).

9) H. H. Uhlig: "Corrosion and Corrosion Control", p. 193, John Wiley and Sons (1963).

10) K. Kasahara, T. Sato and H. Adachi: Mater. Perform., 19, No. 9, p. 45 (1980).

11）笠原晃明，足立晴彦：第 8 回国際金属腐食会議予 稿集. 